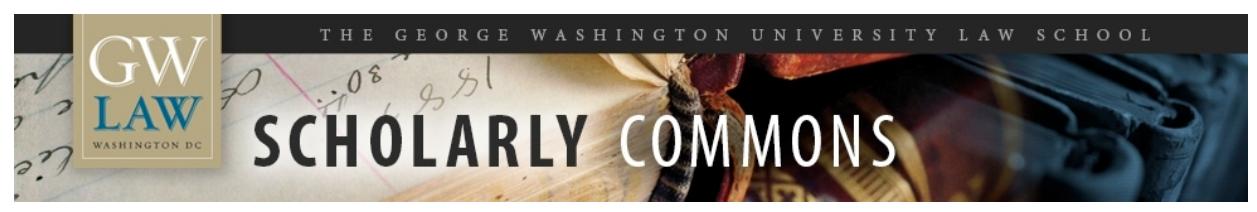

\title{
In the Civic Republic: Crime, the Inner City, and the Democracy of Arms-Being a Disquisition on the Revival of the Militia at Large
}

Robert J. Cottrol

George Washington University Law School, bcottrol@law.gwu.edu

Raymond T. Diamond

Louisana State University, Baton Rouge- Paul M. Herbert Center

Follow this and additional works at: https://scholarship.law.gwu.edu/faculty_publications

Part of the Law Commons

\section{Recommended Citation}

Cottrol, Robert J. and Diamond, Raymond T., In the Civic Republic: Crime, the Inner City, and the Democracy of Arms - Being a Disquisition on the Revival of the Militia at Large (July 2013). Connecticut Law Review, Vol. 45, 2013; GWU Law School Public Law Research Paper No. 2014-12; GWU Legal Studies Research Paper No. 2014-12. Available at SSRN: http://ssrn.com/abstract=2430410

This Article is brought to you for free and open access by the Faculty Scholarship at Scholarly Commons. It has been accepted for inclusion in GW Law Faculty Publications \& Other Works by an authorized administrator of Scholarly Commons. For more information, please contact spagel@law.gwu.edu. 


\section{CONNECTICUT \\ LAW REVIEW}

\section{Article}

In the Civic Republic:

Crime, the Inner City, and the Democracy of ArmsBeing a Disquisition on the Revival of the Militia at

Large

\section{ROBERT J. COTTROL \& RAYMOND T. DIAMOND}

This Article examines the modern utility of the Second Amendment's guarantee of "the right to keep and bear arms" in light of the phenomenon of modern crime, particularly black-on-black violence in urban America. Although many advocates of gun control have argued that crime in modern cities is a reason for modifying or severely truncating the right to have arms, the Authors argue that the right to have arms and the Second Amendment's notion of a universal militia can be the basis of a new partnership between police and citizens in urban America. This new partnership can, if properly developed, be a useful tool in fighting crime in inner-city communities. 


\section{Article ConTENTS}

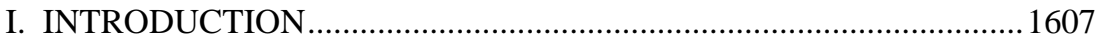

II. THE CATASTROPHIC CHASM.........................................................1611

III. THE SECOND AMENDMENT: OF ARMED CITIZENS AND INCHOATE MILITIAS .1616

IV. THE SECOND AMENDMENT AS MORAL STATEMENT ............1622

V. RACIAL ANTAGONISM AND INEFFECTIVE POLICING .............1628

VI. TOWARD A WELL-REGULATED MILITIA ....................................1632

A. ARMED AND TRAINED AuXILIARIES ...................................................1633

B. An ARMED AND Visible NeighborhoOd WATCH ..............................1634

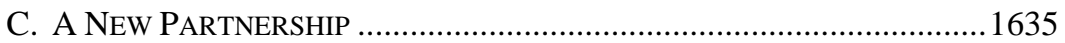

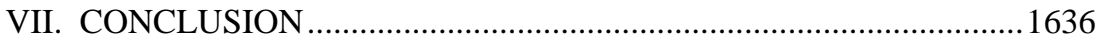

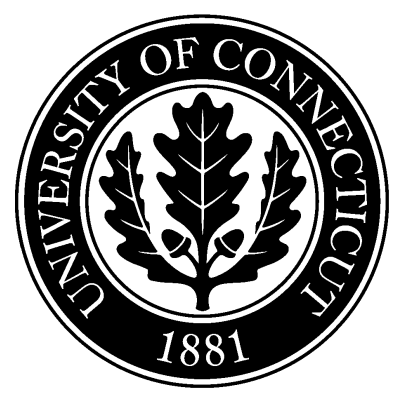




\title{
In the Civic Republic: Crime, the Inner City, and the Democracy of Arms- Being a Disquisition on the Revival of the Militia at Large
}

\author{
ROBERT J. COTTROL ${ }^{*} \&$ RAYMOND T. DIAMOND ${ }^{* *}$
}

\section{INTRODUCTION}

Nicholas Johnson's important and timely article brings to the forefront of our considerations one of the more tragic and puzzling aspects of our national debate over the Second Amendment and firearms policy. How might we account for the seemingly large-scale support for measures restricting access to firearms among African-Americans, particularly black political leaders? The irony is clear. A segment of the American population that has, historically and indeed in modern times, been all too frequently unable to rely on the state for protection has produced a political leadership that can usually be relied on to support measures that at the end of the day will limit the right of self-defense for its constituents. ${ }^{1}$ The path to this current paradoxical set of circumstances has been a tortured one. There is a long history concerning race and the right to bear arms that had enjoyed only relatively sporadic engagement by legal historians and historians of the Civil Rights movement until relatively recently. ${ }^{2}$ It is an area that began to gather greater attention in the 1990s and the early part of our new twenty-first century as the debate over the Second Amendment

\footnotetext{
* Harold Paul Green Research Professor of Law, and Professor of History and Sociology, The George Washington University.

${ }^{* *}$ Jules F. \& Francis T. Landry Distinguished Professor of Law, and Vice Chancellor for Institutional Assessment and Faculty Development, Louisiana State University Law Center.

${ }^{1}$ See Nicholas J. Johnson, Firearms Policy and the Black Community: An Assessment of the Modern Orthodoxy, 45 ConN. L. REV. 1491, 1554-67 (2013) [hereinafter Johnson, Firearms Policy] (recounting the national gun control movement in the 1960s and 1970s that embraced the progressive program of supply-side gun control as an answer to crime and civil unrest).

${ }^{2}$ See, e.g., Lance Hill, The Deacons for Defense: ARMed Resistance and the Civil Rights Movement 2 (2004) (detailing the history of the Deacons for Defense and Justice, an armed self-defense organization formed in southern black communities in the 1960s to protect AfricanAmerican communities and civil rights workers from the Ku Klux Klan and other violent racist groups). Another indication of growing interest in the topic among civil rights historians was the panel entitled "Armed Self Defense during the 1950s and 1960s: The Other Side of the Southern Civil Rights Movement” held at the American Historical Association in January 2013. AM. HIST. Ass'N, PROGRAm OF THE 127Th AnNual MeEting 69 (Sharon K. Tune \& Debbie Ann Doyle eds., 2013), available at http://www.historians.org/annual/2013/2013AMProg.pdf.
} 
and the potential limitations it might pose for gun control policies began to heat up. With the decisions in District of Columbia v. Heller ${ }^{3}$ and McDonald v. City of Chicago, ${ }^{4}$ and especially with Justice Thomas's concurring opinion in McDonald, the idea that the right to keep and bear arms and its place in the American constitutional order had to be assessed in light of the nation's history of racial violence was placed on a firmer and surer footing. ${ }^{5}$ The willingness of historians of race relations and the civil rights movement to reexamine the importance of armed self-defense to what was, in the final analysis, an essentially nonviolent movement to challenge the American version of apartheid-Jim Crow-has added an important nuance to our understanding of the complexities of the struggle for equal rights in the American nation and to our understanding of the importance of a right to arms for a people long denied the state's protection. $^{6}$

In Firearms Policy and the Black Community: An Assessment of the Modern Orthodoxy, Professor Johnson takes us through what should be, but is often not, a familiar syllabus of the Afro-American experience. ${ }^{7}$ The Negroes who inhabited the American Republic of the nineteenth and first six decades of the twentieth century were courageous men and women whose very lives often depended on their abilities to defend themselves against racial violence in a nation that applauded, or at least silently abetted racial violence directed against them. ${ }^{8}$ Far from the stereotyped trembling black victims passively and fearfully awaiting the deprivations of the Klan, lynch mobs, or other more impromptu progenitors of racial violence, they defended themselves with firearms, at times against daunting odds. ${ }^{9}$ This was true even before the South's defeat in the War of the Rebellion. In Northern cities, free Afro-Americans recognized the importance of armed resistance to slave hunters anxious to return fugitives to lives of bondage, and when they could, reduce free Negroes to the conditions of slaves. ${ }^{10}$ Black men and women who resisted the Jim Crow order that was overtaking the South and the nation at the end of the nineteenth and beginning of the twentieth centuries recognized that neither unarmed passivity nor unarmed defiance would stop a lynch mob

${ }^{3} 554$ U.S. 570 (2008).

${ }^{4} 561$ U.S. 3025 (2010).

${ }^{5}$ See id. at 3058-88 (2010) (Thomas, J., concurring) (advocating for the incorporation of the Second Amendment to laws passed by the states pursuant to the Fourteenth Amendment's Privileges or Immunities Clause).

${ }^{6}$ See id. at 3036 (majority opinion) (noting that the earlier Heller decision made it clear that the right to bear arms is "deeply rooted in this Nation's history and tradition” (citation omitted)).

${ }^{7}$ See Johnson, Firearms Policy, supra note 1, at 1497-1516.

${ }^{8}$ Id.

${ }^{9} I d$.

${ }^{10}$ See, e.g., James O. HORTON \& LOIS E. HoRTON, Black Bostonians: Family Life AND COMMUNITY STRUGGLE IN THE ANTEBELLUM NORTH 102-14 (1979). 
determined to torture and kill, or a mob of rioters determined to burn down homes in a black neighborhood. These lessons were impressed on civil rights leaders A. Philip Randolph and Walter White early in their lives. ${ }^{11}$ These lessons learned in the early twentieth century and kept alive through the 1960s by self-defense groups like the Deacons for Defense and Justice played a role — one that has still not been fully appreciated —in the ultimate triumph of the American Civil Rights movement. The security provided by armed groups like the Deacons often meant the difference between life and death for workers engaged in voter registration and other civil rights organizing efforts. Without that security, the civil rights movement that transformed the South and the nation could very well have died a very early death. ${ }^{12}$

Those of us who have pointed out this history and have used it as part of the argument for a robust individualistic interpretation of the Second Amendment have often been met with a counterargument that runs along the following lines: What you have said, as a matter of history, is largely true. Private arms in the hands of black communities in the Jim Crow era did play a role in combating the Klan and other practitioners of racial violence. We may debate exactly how effective such actions were, but some of them were undoubtedly necessary in an era when the federal government was essentially failing to protect the civil and constitutional rights of racial minorities. But we live in a different day. There is a robust regime of federal civil rights law and law enforcement. And state governments, even conservative southern state governments, have to contend with an enfranchised African-American population. Even the most reactionary of state regimes will no longer tolerate the kind of racial violence, the lynch law, that prevailed in the past. The case for private arms, they argue cannot be based solely on a past that is rapidly receding from lived memory into studied history. ${ }^{13}$

${ }^{11}$ See Jervis Anderson, A. Philip Randolph: A Biographical Portrait 41-42 (1973); Walter White, A Man Called White: THe Autobiography of Walter White 5-12 (1948) (recounting childhood experiences with racist lynch mobs threatening him and his family).

${ }^{12}$ Any discussion of armed resistance as part of the postwar Civil Rights movement should include the story of Robert Williams, who was an NAACP organizer in North Carolina in the late 1950s. See Timothy B. Tyson, Introduction to RoBert F. Williams, NEgroes WITH Guns, at vii-xii, XV-xxviii (Wayne St. Univ. Press 1998) (1962) (noting that Negroes with Guns "affords us the best available view of a remarkable mind of the South, Robert F. Williams, one of the most dynamic race rebels of a generation that changed the world”); see also HILL, supra note 2, at 288-89 n.31 (describing the Deacons of Defense's efforts to initiate voter registration and the violent backlash from the white population).

${ }^{13}$ Whether or not the kind of racial violence that existed in the South and other regions of the nation through the 1960s is now safely in the rearview mirror of the nation's history is still, in our view, an open question. In November 2012, the Combating Terrorism Center at the United States Military Academy at West Point issued a report indicating that the United States still faced a terrorist threat from far-right, usually racist, groups. ARIE PERLIGER, CHALlengers FROM THE Sidelines: 
The critics of our explorations of the history of racial violence and the role of private arms in combating such go further. They argue, with considerable justification, that the threat to black lives today is not the Klansman of yesteryear, but the tragic phenomenon of black-on-black violence on the mean streets of modern urban America. The concern is real. Violent crime is a plague on inner-city Black communities even today at the beginning of the twenty-first century. The black homicide rate is high, way too high. Homicide figures for the year 2008 illustrate this point. That year the national homicide rate was 5.4 per $100,000 .{ }^{14}$ For whites the figure was 3.3 per 100,000 and for blacks it was 19.6 per $100,000{ }^{15}$ For young black men ages 18 to 24 , the homicide rate per 100,000 for that year was a staggering 91.1 per $100,000 .{ }^{16}$ These figures, these devastating statistics representing the frightening modern reality of black-on-black crime, are what has led many African-American political and social leaders and, indeed, ordinary folk to support stricter gun control for the nation at large and particularly for inner-city black communities. It is a recognition of the desperate circumstances found in all too many poor, black communities. Many argue that the Second Amendment, the attendant idea that there is a real right to own firearms for self-defense, and the corollary notion that the Constitution places real, enforceable limits on gun restrictions is a dangerous, intervention that exacerbates rather than alleviates the problem.

We believe that the question of the Second Amendment and its relationship to the contemporary tragedy that is inner-city violence should be looked at in a new light. That new light forces us to consider and propose a policy option with which we are not entirely comfortable. Like Professor Johnson, we have had an ongoing interest in the issue of the right to bear arms as a cultural, legal, and political norm in Anglo-American history. ${ }^{17}$ Like Nicholas Johnson, we have also had strong concerns with

UNDERSTANDING AMERICA's VIOLENT FAR-RIght 3-4 (Nov. 2012), available at http://www.ctc.usma.edu/wp-content/uploads/2013/01/ChallengersFromtheSidelines.pdf.

${ }^{14}$ U.S. Census Bureau, 2012 Statistical ABStract: National DATA BOOK 200 tbl.312 (2012), available at http://www.census.gov/compendia/statab/cats/law_enforcement_courts_prisons/cri mes_and_crime_rates.html.

${ }^{15} I d$.

${ }^{16}$ Alexia Cooper \& Erica L. Smith, U.S. Dep'T of Justice, Bureau of Justice Statistics, Patterns \& TRENDS: Homicide TRENDS IN THE United StATES, 1980-2008, at 14 (2011) [hereinafter HOMICIDE TRENDS IN THE UNITED STATES], available at http://www.bjs.gov/content/pub/pdf/htus8008.pdf.

${ }^{17}$ See, e.g., Robert J. Cottrol \& Raymond T. Diamond, Public Safety and the Right to Bear Arms, in THE Bill OF RightS IN MOdern America 88, 89-90 (David J. Bodenhamer \& James W. Ely, Jr. eds., 2008) (tracing the Second Amendment's roots and development, starting with British common law and community security); Robert J. Cottrol \& Raymond T. Diamond, The Second Amendment: Toward an Afro-Americanist Reconsideration, 80 GEO. L.J. 309, 319 (1991) (arguing that "Second Amendment issues need to be explored, not only with respect to how the right to keep and bear arms 
how that concept has been shaped and perhaps how it should yet be shaped by the experience of racial inequality in American society. Here we propose to link three now-separate conversations: (1) the debate over the right to arms; (2) our longstanding concerns over police misconduct; and (3) the concern over the tragic level of black-on-black violence. The bulk of our previous efforts discussing the right to arms, like Nicholas Johnson's discussion in Firearms Policy and the Black Community, have concentrated on historic black-white conflict, particularly in the South, and how that conflict helped influence cultural, legislative, and judicial attitudes concerning the right to arms. ${ }^{18}$ We hope in this Article to bring that conversation to a new venue. Today we are concentrating on the all too modern question of contemporary black-on-black crime in American cities in the still-young twenty-first century. That phenomenon forces us to ask new questions concerning the right to keep and bear arms and its irrelevance or importance in modern urban society. As was the case with our previous writings on the subject, we believe that though we are writing with the Afro-American experience in mind, we are posing questions that have a wider relevance to other peoples and, indeed, other societies.

\section{THE CATASTROPHIC CHASM}

Let us begin with an observation that should at once be obvious and yet is often forgotten. With all the talk in the media and in the halls of state legislatures and Congress about a crisis of crime and gun violence, it should be stressed that in all too many inner-city communities, crime and violence-both violence committed with firearms and with other weapons - have long ago passed from crisis to catastrophe. Catastrophic violence in some communities has become so common that it rarely gets noticed; or becomes the occasion for national calls to action. President Obama and the nation were rightly horrified when Adam Lanza slayed twenty children and six administrators and teachers at Sandy Hook Elementary in Newtown, Connecticut. ${ }^{19}$ The slayings prompted a national

has affected American society as a whole, but also with an eye toward subcultures in American society who have been less able to rely on state protection”).

${ }^{18}$ For our discussion of the role played by racial conflict and racial subordination in helping to produce a somewhat narrow jurisprudence concerning the right to keep and bear arms, see Robert J. Cottrol \& Raymond T. Diamond, “Never Intended to Be Applied to the White Population": Firearms Regulation and Racial Disparity-The Redeemed South's Legacy to a National Jurisprudence?, 70 CHI.-Kent L. REV. 1307, 1311 (1995) [hereinafter Cottrol \& Diamond, Never Intended] (exploring "questions raised by restrictive firearms legislation and the response of state judiciaries to that legislation" and ultimately discussing the "difficulty of separating diverse racial and other motives behind the enactment of the statutes under consideration, the judicial response to such statutes, and the adoption of Southern precedents in this area in other jurisdictions”).

${ }^{19}$ Andy Newman, Dec. 16 Updates on Connecticut Shooting Aftermath, N.Y. TIMEs LEDE BLOG (Dec. 16, 2012, 11:00 AM), http://thelede.blogs.nytimes.com/2012/12/16/sunday-coverage-ofnewtown-school-shooting/. 
debate and calls for action at the national level. ${ }^{20}$ If the utility, advisability, and constitutionality of some of the proposed measures might be questioned, the tragic and incomprehensible murders in Newtown nonetheless did focus the country's attention on the tragedy of violence in national life. But, the far greater rate of crime and violence in the nation's ghettos and its devastating impact for a significant segment of the population remain largely off the national radar screen. Violent crime has made homicide the leading cause of death of young black men. ${ }^{21}$ Violent crime leads to well-justified fears for the physical safety of children in inner-city schools. ${ }^{22}$ Violent crime robs elderly ghetto residents of the serenity that age, toil, and a life of keeping faith with an often-faithless society should have won for them. Violent crime chases businesses out of ghettos, insuring ever-dwindling opportunities for those who cannot escape inner-city neighborhoods that for far too many residents are simply urban prisons. ${ }^{23}$ The appallingly high rate of inner-city crime, a product of the culture of despair that has developed in the modern inner city, insures that this culture will continue and worsen as we continue on with the twentyfirst century.

Part of the reason for the catastrophe that is inner-city black crime has to do with longstanding patterns of estrangement and mutual distrust between poor black communities and police departments. This estrangement has allowed violent microcultures of dangerous criminals to

\footnotetext{
${ }^{20} I d$.

${ }^{21}$ In 2009, the latest year for which data is fully available, homicide was the leading cause of death in the United States for non-Hispanic black males between the ages of 15-19, 20-24, and 25-34, which accounts for $50.4 \%$ of such deaths in the 15-19 age range, $49.2 \%$ in the 20-24 range, and $32.8 \%$ in the 25-34 range. Ctrs. For Disease Control \& Prevention, National Vital Statistics REPORTS, DEATHS: LEADING CAUSES FOR 2009, at 34 tbl.1 (2012), available at http://www.cdc.gov/nchs/data/nvsr/nvsr61/nvsr61_07.pdf.

${ }^{22}$ See Samantha Neiman \& Monica R. Hill, Nat’L Ctr. For Educ. Statistics \& U.S. DeP’T of Educ., CRime, Violence, Discipline, AND SAFETy in U.S. Public SCHOOlS: FindingS From the SCHOOL SURVEY ON CRIME AND SAFETY: 2009-10, at 3, 7 tbl.1 (2011), available at http://nces.ed.gov/pubs2011/2011320.pdf (finding that there were 25 violent incidents of crime per 1,000 students in public schools in the 2009-2010 school year). In addition,

[s]ome 46 percent of schools reported at least one student threat of physical attack without a weapon, . . . 8 percent . . . with a weapon. Some 25 percent of schools reported at least one incident of the distribution, possession, or use of illegal drugs, a higher percentage than that of the distribution, possession, or use of alcohol (14 percent of schools) or prescription drugs (12 percent of schools). Some 10 percent of city schools reported at least one gang-related crime, a higher percentage than that reported by suburban ( 5 percent), town (4 percent), or rural schools (2 percent).

Id. at 7 (citations omitted).

${ }^{23}$ See, e.g., Trymaine Lee, In Newtown's Shadow, Chicago's Bleak Gun Toll Goes On, MSNBC (Dec. 20, 2012), http://tv.msnbc.com/2012/12/20/in-newtowns-shadow-chicagos-bleak-gun-toll-goeson/ (describing how "court cases and law enforcement costs related to gun violence, as well as indirect costs associated with residents and businesses leaving the city because of fear of crime and violence are extraordinary" in Chicago).
} 
survive and, in some cases, flourish in all too many inner-city communities. $^{24}$ A recent study conducted at the University of Illinois at Chicago documents part of the problem in one important city. The study, Crime, Corruption and Cover-Ups in the Chicago Police Department, paints a frightening portrait of a big city police department where much has gone wrong. ${ }^{25}$ Corruption and brutality, including the torture of prisoners to produce confessions, while not routine, are common enough that they cannot be dismissed as fluke occurrences or isolated incidents. ${ }^{26}$ And the problems faced by inner-city residents do not end with the phenomena of police corruption and brutality. Far more insidious is the routine problem of under-protection of inner-city communities. Under-protection shows up in slower emergency service response times, or longstanding beliefs on the part of ghetto residents that they are the victims of slower response times. ${ }^{27}$ Inner-city residents have long believed, with considerable justification, that their lives and property are undervalued by municipal governments, even in many cases by municipal governments responsible to electorates that are largely poor and black, even in cities where the municipal authorities, including senior police officials, are African-American. ${ }^{28}$

Brutality and under-protection are more than the occasional price paid by unfortunate individual African-Americans who encounter either hostile or indifferent police officers. Instead the regular pattern of encounters between inner-city residents and police contributes to estrangement and mutual distrust on a daily basis. These sentiments are fueled by the relatively rare but still alarmingly high and often dramatic incidents of police brutality. ${ }^{29}$ They are also fueled by the more common hostile

\footnotetext{
${ }^{24}$ See generally Robert J. Cottrol, Submission Is Not the Answer: Lethal Violence, Microcultures of Criminal Violence and the Right to Self-Defense, 69 U. COLO. L. REV. 1029, 1033-34 (1998) (arguing, in part, that there are "subcultures in American society that produce highly violent microcultures and that these subcultures have very few counterparts in other western nations").

${ }^{25}$ John Hagedorn et Al., Crime, Corruption and COVER-Ups in the Chicago Police DEPARTMENT: ANTI-CORRUPTION REPORT NUMBER 1 (2013), available at http://www.uic.edu/depts/pols/ChicagoPolitics/policecorruption.pdf.

${ }^{26}$ Id. at $1-2$.

${ }^{27}$ See, e.g., Steve Vogel, Poor Areas Wait Longer for Hard-Pressed D.C. Police, WASH. PosT, June 2, 1996, at A01 (describing how "[r]esidents in many of the District's poorest neighborhoods routinely wait hours longer for police to respond to non-life-threatening calls than do residents in affluent areas”).

${ }^{28} I d$.

${ }^{29}$ In the United States in 2002, large municipal police departments with 1,000 or more full-time sworn police officers received 3.64 force complaints per 10,000 population, with $6 \%$ of the complaints sustained. U.S. Dep't of Justice Bureau of Justice Statistics, Citizen Complaints About POLICE USE OF FORCE 4 tbl.4, tbl.5 (2006), available at http://bjs.gov/content/pub/pdf/ccpuf.pdf. Departments with 500-999 sworn officers received 2.49 complaints per 10,000 population, with $15 \%$ sustained. Id. Departments with 250-499 sworn officers received 1.66 complaints per 10,000 population, with $13 \%$ sustained. Id. Departments with 100-249 sworn officers received 0.86 complaints per 10,000 population, with $9 \%$ sustained. Id.
} 
encounters between police and citizens on the streets, encounters often characterized by mutual fears and wary anticipations. ${ }^{30}$ But, mostly, this estrangement is the product of the well-justified belief on the part of many ghetto residents that the police and, indeed, the whole criminal justice system, are indifferent to their plight and are largely unwilling to take effective action to protect them from the predators that they are forced to live amongst. ${ }^{31}$ Police departments have a history—well known to innercity residents - of failing to treat the victimization of the inner-city poor as seriously as they treat crime in other segments of society. ${ }^{32}$ For all too many inner-city communities, the police have historically not been regarded as a concerned force willing and able to protect their lives, limbs, and limited property. ${ }^{33}$ Instead, the police have often been seen as ineffective and unconcerned at best, or as an occupying army of outsiders at worst. $^{34}$

To close out this admittedly grim picture, it should be stressed that the often sad state of police-community relations in the inner city cannot simply be attributed to naked racism-as tempting as that explanation might be. To be sure, historical and indeed modern police departmentslike other elements of society-have not lacked for racists in their ranks, and indifference to the plight of black victims of crime has a long and ignoble history in American criminal justice. ${ }^{35}$ But today, we would urge

\footnotetext{
${ }^{30}$ See Douglas A. Smith, The Neighborhood Context of Police Behavior, 8 CRIME \& JUST. 313, 337 (1986) (finding that "suspects confronted by police have a higher average probability of being arrested in lower-status neighborhoods than in higher-status areas"); see also IAN AYRES \& JONATHAN Borowsky, A STUdy OF Racially Disparate Outcomes in the LOS ANgeles Police DEPARTMENT, at i (2008), available at http://islandia.law.yale.edu/ayres/Ayres\%20LAPD\%20Report.p df (stating that, per 10,000 residents, the black stop rate was 3,400 stops higher than the white stop rate; relative to stopped whites, stopped blacks were $127 \%$ more likely to be frisked, $76 \%$ more likely to be searched, and 29\% more likely to be arrested; frisked African Americans were $42.3 \%$ less likely to be found with a weapon than frisked whites; and yet, consensual searches of blacks were $37 \%$ less likely to uncover weapons, $23.7 \%$ less likely to uncover drugs and $25.4 \%$ less likely to uncover any other contraband).

${ }^{31}$ JoHn L. COOPER, THE POLICE AND THE GHETTO 133 (1980).

${ }^{32}$ See id. (explaining how many ghetto residents believe the police are indifferent to internally directed violence that does not have effects on places of business or white neighborhoods).

${ }^{33}$ See id. ("[I]n the final analysis, [ghetto residents] do not see the police there to protect them."); see also Dan Baum, Deluged, New YORKER, Jan. 9, 2006, at 50, 52 ("The N.O.P.D. was notorious long before Katrina for failures of leadership, professionalism, and discipline.”).

${ }^{34}$ See COOPER, supra note 31, at 132 ("The residents of Harlem do feel like they live in an occupied community with so many police among them, but there has been no war fought in Harlem that was so bloody that a 'peace-keeping force' was necessary.”).

${ }^{35}$ See, e.g., COOPER, supra note 31, at 135 ("More than 2,595 blacks were lynched in the South between the years 1882 and 1959. Not one white person was ever brought to trial for those crimes.... It was the Southern police who backed the KKK, often themselves being members of the Klan.” (footnote omitted)); Civil Rights Division, U.S. DEP'T OF JUSTICE, INVESTIGATION OF THE NEW ORLEANS Police DePARTMENT 34-36 (2011) (finding reasonable cause to believe that the N.O.P.D. engaged in a pattern or practice of unconstitutional discriminatory policing, and reporting perceptions of policing bias by African American and ethnic minority communities).
} 
that something more is at work. The problems of brutality and underprotection persist in the inner city-even in those cities led by black politicians with black police chiefs, and with large numbers of black police officers on the force. ${ }^{36}$ To explain the persistence of the traditional patterns we must recognize that, while racism is still an element of the problem, something more is at work.

The persistence of traditional patterns of under-protection in inner-city communities might be simply explained by the relative lack of political pull and social capital of many inner-city residents. A murder of a middleclass white person, or in many cases even that of a middle-class black person, mobilizes a community in a way that does not occur when a poor resident of a dangerous neighborhood is killed. In the former case, the press covers the story. The victim's name and details of her life story are published in the local newspaper and broadcast on local radio and television. The murder of a poor resident in a dangerous neighborhood is usually ignored. The difference probably has less to do with racism as we once might have classically defined it, and more to do with the fact that those who are able to make noise in our society (e.g., reporters and educated people who are likely to write op-ed pieces and letters to the editor or be convincing spokespersons on radio and television) are more likely to identify with the middle-class victim than with the poor one from the dangerous neighborhood. In any event, the personalization of the victim's story brings political pressure on the police department to find the culprit. Additional police resources are devoted to solving the crime. The killing of the identifiable middle-class victim is noticed and acted upon. The murder victim in the ghetto becomes a forgotten statistic.

We are faced with catastrophic crime rates, police forces marred by the evils of under-protection and brutality, and a society that seems all too willing to ignore the victimization of the powerless. So where does the right to keep and bear arms - the Second Amendment, if you will-come into this discussion? What relevance does this remnant of seventeenthcentury English Whiggery ${ }^{37}$ have to our discussions of police-community

${ }^{36}$ See COOPER, supra note 31, at 110 ("To demonstrate that they showed no favoritism . . . black police officers would willingly 'beat the heads' of blacks, in the name of maintaining law and order.”); Al Baker, Progress in Promoting Black Officers, but Police Department Faces Hurdles, N.Y. TIMES, May 11, 2008, at A31 (noting that, despite some improvements in their relations, tensions persist between diverse communities and the increasingly diverse New York City police force); Michael S. Serrill et al., The New Black Police Chiefs, Time, Feb. 18, 1985, at 84 ("The police chiefs of four of the nation's six largest cities - New York, Chicago, Houston and Detroit-are now black, as are twelve of the top police officials in the 50 largest cities.”).

${ }^{37}$ For the definitive discussion of how political developments in seventeenth-century England helped bring the right to bear arms into Anglo-American constitutionalism, see generally JOYCE LEE Malcolm, To KeEP And BeAr Arms: The Origins of AN ANGlO-AmERICAN Right (1994). See also Robert J. Cottrol \& Raymond T. Diamond, The Fifth Auxiliary Right, 104 YALE L.J. 995 (1995) (reviewing Malcolm's book). Malcolm explained that the right to keep and bear arms under the 
relations and the mean streets of our unacceptably dangerous inner-city communities of the early twenty-first century? To answer that question it is necessary to back up and say a few words about the Second Amendment, the quality of the debate over the Second Amendment, and the direction that debate should take in the future.

\section{THE SECOND AMENDMENT: OF ARMED CiTIZENS AND INCHOATE MiLitias}

The Second Amendment debate has, of course, been an inescapable feature of American public life for the better part of a generation. The Second Amendment has famously been subject to two instrumental interpretations by partisans on different sides of the gun control debate. Proponents of stricter gun controls have tended to stress the Amendment's first clause-arguing that the Second Amendment was either designed to protect the right of states to maintain militias free from potential encroachment by the newly formed and feared federal government, ${ }^{38}$ or, more recently, that it was designed to protect the right to bear arms only within the context of an organized and highly regulated militia. ${ }^{39}$ This argument was made by twentieth-century legal commentators such as Lucilius A. Emery, the former Chief Justice of the Supreme Judicial Court of Maine, and Roscoe Pound, the former Dean of Harvard Law School,

English Bill of Rights was supposed to serve the purposes of self-defense, common defense, and law enforcement, and also constitute a check on government. Anthony Gallia, Comment, "Your Weapons, You Will Not Need Them." Comment on the Supreme Court's Sixty-Year Silence on the Right to Keep and Bear Arms, 33 AKRon L. REV. 131, 147 (1999).

${ }^{38}$ See Don B. Kates, Jr., Handgun Prohibition and the Original Meaning of the Second Amendment, 82 МicH. L. REV. 204, 211-12 (1983) (describing how proponents of the states' rights viewpoint believe that the Second Amendment has been "rendered anachronistic" over time).

${ }^{39}$ See Robert A. Creamer, Note, History Is Not Enough: Using Contemporary Justifications for the Right to Keep and Bear Arms in Interpreting the Second Amendment, 45 B.C. L. REV. 905, 905-06, (2004) (nesting this concept under the label of a "collective or states' right view”). The judicial source of the collective rights view, Stephen Halbrook says, may likely be traced back to Tot $v$. United States, 319 U.S. 463 (1943). Stephen P. Halbrook, Panelist Remarks at the Seton Hall Constitutional Law Journal Symposium: Second Amendment (Summer 2000), in 10 SETON HALl CONST. L.J. 815, 818 (2000). This collective rights view was commonly upheld in federal circuit courts. See United States v. Hale, 978 F.2d 1016, 1019 (8th Cir. 1992) ("[A]bsent a showing that the possession of a certain weapon has 'some reasonable relationship to the preservation or efficiency of a well-regulated militia,' the Second Amendment does not guarantee the right to possess a weapon.” (quoting United States v. Miller, 307 U.S. 174, 178 (1939))); Quilici v. Village of Morton Grove, 695 F.2d 261, 270 (7th Cir. 1982) (“Construing [the Second Amendment's] language according to its plain meaning, it seems clear that the right to bear arms is inextricably connected to the preservation of a militia."); United States v. Oakes, 564 F.2d 384, 387 (10th Cir. 1977) ("The purpose of the second amendment ... was to preserve the effectiveness and assure the continuation of the state militia." (citing Miller, 307 U.S. at 178)). United States v. Emerson, 270 F.3d 203 (5th Cir. 2001), helped stir further debate leading up to District of Columbia v. Heller, 554 U.S. 570 (2008), by bucking the trend of the federal courts and opposing the collective rights view. Emerson, 270 F.3d at 260. 
among others. ${ }^{40}$ They urged an instrumental reinterpretation of the right to keep and bear arms, one that would redefine the right as one confined to the militia or those performing militia service. ${ }^{41}$ This redefinition would make possible the increased regulation of firearms that they saw as necessary public policy. ${ }^{42}$ Opponents of stricter gun controls have argued the opposite. They stress the Amendment's second clause, arguing that the mention of "a well regulated militia" should be viewed as an amplifying rather than a qualifying clause. In their view, maintaining a militia of the whole citizenry armed with privately-owned weapons was but one reason for securing the people's right to bear arms; the Amendment was also designed to secure the citizen's right to bear arms for private purposes, including the right to self-defense. ${ }^{43}$ This view was accepted by narrow majorities in the Supreme Court's first pair of fully litigated considerations of the meaning and scope of the Second Amendment in McDonald and Heller. $^{44}$

Space does not allow for an extended exposition of the debate over the intentions and understandings of the eighteenth-century framers and ratifiers who put the Second Amendment into the Constitution. Nor will space permit re-examination of the history surrounding the adoption of the Fourteenth Amendment and the role that the denial of the right to bear arms of the newly freed black population played in convincing the 39th Congress of the need to apply the Bill of Rights to the states. ${ }^{45}$ That

${ }^{40}$ See Cottrol \& Diamond, Public Safety and the Right to Bear Arms, supra note 17, at 99 (discussing Emery's writings); Robert J. Cottrol, The Resurgent Second Amendment, 47 TULSA L. REV. 1, 6 (2011) (book review) (discussing Pound's writings).

${ }^{41}$ See Roscoe Pound, The Development of Constitutional Guarantees of Liberty 8991 (1957) (discussing the historical origins of the right to bear arms, and arguing against a generalized right to do so in modern society); Lucilius A. Emery, The Constitutional Right to Keep and Bear Arms, 28 HARV. L. REV. 473, 476 (1915) (arguing that the right to bear arms should be interpreted as inherently limited to organized military settings).

${ }^{42}$ See Pound, supra note 41, at 91 ("Here is the one provision of the Bill of Rights that seems to have been able to achieve nothing for us."); Emery, supra note 41, at 477 ("I venture the opinion that, without violence to the constitutional guaranty of the right of the people to bear arms, the carrying of weapons by individuals may be regulated, restricted, and even prohibited according as conditions and circumstances may make it necessary for the protection of the people.”).

${ }^{43}$ Creamer, supra note 39, at 906. Before Heller, the individual rights view had been embraced by a majority of legal scholars. During the preceding twenty-five years, new works exploring the history behind the Second Amendment had a profound influence on individual rights scholarship. Clark Neily, District of Columbia v. Heller: The Second Amendment Is Back, Baby, 2007-2008 CATO Sup. CT. Rev. 127, 131 (2008). The post-ratification commentary, pre-Civil War case law, post-Civil Civil War legislation, and early post-Civil War commentary also support this individual rights view. Heller, 554 U.S. at 605-18.

${ }^{44}$ McDonald v. City of Chicago, 130 S. Ct. 3020, 3050 (2010) (5-4 decision); Heller, 554 U.S. at 594 (5-4 decision).

${ }^{45}$ For a comprehensive look at the role of the right to keep and bear arms in the consideration of the Fourteenth Amendment and the civil rights legislation of the Reconstruction Era, see generally 
territory has been covered in the legal and historical literature, was extensively briefed in McDonald and Heller, and was reflected in those cases' majority, concurring, and dissenting opinions.

Still, the modern debate over the Second Amendment requires comment. In our view, the debate over whether the Second Amendment should be seen in solely individual-centric or solely militia-centric terms sets up a false dichotomy. Little in the history, the statements of eighteenth- and nineteenth-century commentators, the text of the amendment, or even the scant treatment afforded the issue by the Supreme Court before McDonald and Heller justifies the view that the Second Amendment was simply meant to safeguard the right of states to maintain militias without also safeguarding an individual right to arms. ${ }^{46}$ Nor does the history of the militia support the contention that the right was conditioned upon active membership in an organized militia—a militia whose membership would always be determined by the state or the federal government, and not the people whose right is presumably protected by the Second Amendment's very language. ${ }^{47}$ When the history of the Fourteenth Amendment is added to our considerations, the view that the Constitution was not meant to protect an individual right to arms becomes totally unsupportable - a result-oriented piece of constitutional denial that can and should be readily dismissed. ${ }^{48}$

StePHEN P. HALbRoOK, FREEDMEN, the FourteENTH AMENDMENT, AND tHe Right to BEAR ARMS, 1866-1876 (1998).

${ }^{46}$ The most notable English common law commentators noted that there was a right to keep arms for self-defense in the home. Blackstone held the right in high esteem, considering it an absolute individual right. Further, the English Parliament recognized the right in light of the disarming English Game Acts, after the Glorious Revolution led to the overthrow of the Stuarts. Kates, Jr., supra note 38, at 240. This recognition of the right to keep and bear arms as essential, pre-existing, and being individual in nature continued in the earliest American legal commentaries. For example, St. George Tucker, William Rawle, and Justice Joseph Story all published works supporting an individual rights view of the Second Amendment. Moreover, founders and early legislators, such as James Madison, were around at the time these works were being published and read. None of these creators of the law spoke out against those then well-settled interpretations of the Second Amendment. Id. at 241-43. Most notably, the commentary of Tench Coxe, a famous Federalist writer and contemporary of James Madison, interprets the Second Amendment in its immediate aftermath and concludes that it contains a grant of an individual right. Madison commended Coxe on his interpretation and support for the Bill of Rights. Halbrook, supra note 31, at 818.

47 See Cottrol \& Diamond, The Second Amendment: Toward an Afro-Americanist Reconsideration, supra note 18, at 323-27 (discussing the broad-base nature of the militia, specifically in the colonial era before the enactment of the Second Amendment); id. at 327-31 (discussing same during the Revolution); id. at 331-33 (discussing same immediately after the enactment of the Second Amendment); id. at 333-39 (discussing the broad-based militia and racial limitations in antebellum America).

${ }^{48}$ The legal application and use of the Fourteenth Amendment as a tool of incorporation has evolved dramatically throughout the Fourteenth Amendment's history, but the history surrounding its inception and what has since become settled jurisprudence make the position that the Second Amendment should not be applicable to the states through the Fourteenth Amendment seem absurd. First, cases like Presser v. Illinois, 116 U.S. 252 (1886), following United States v. Cruikshank, 92 U.S. 
The realization that the Second Amendment is properly read in individualistic terms - and that Justice Scalia's majority opinion in Heller came closer to the mark than Justice Stevens's and Justice Breyer's dissenting opinions ${ }^{49}$ - still raises the question of how we should conceive of the relation between the citizen, whose right to have arms is now judicially recognized, and the well-regulated militia that the Second Amendment maintains is necessary to the security of a free state. If the effort of the gun control movement to make the militia a limitation on the right to bear arms should be seen as problematic, the linking of the right to keep and bear arms and the well-regulated militia in one constitutional provision does suggest that the two concepts cannot and indeed should not

542 (1876), are part of a vacated jurisprudence that would tend to conflict with "the entire doctrinal basis of modern incorporation of the Bill of Rights against state and local government.” Kates, Jr., supra note 38, at 252-53. The incorporation doctrine has settled that incorporated rights are those that are found to be fundamental-either through long-established common law or based on how highly founders valued the right. Id. at 254. Second, the Second Amendment's historical roots strongly support an individual right to keep and bear arms that is enforceable against the states. See Ronald S. Resnick, Private Arms as the Palladium of Liberty: The Meaning of the Second Amendment, 77 U. DET. MERCY L. REV. 1, 40-41 (1999) (surveying remarks of such framers as Hamilton, Jefferson, Henry, Mason, and Madison). The Fourteenth Amendment was an attempt to enforce civil rights legislation at the end of the Civil War. The civil rights legislation would, in turn, ensure southern blacks of their fundamental rights in the face of local governments. The disarmament of blacks was a concern to congressional legislators, because it led to their further victimization as easy targets for racist mobs that were armed. Gun laws were also used to deny equal protection to new American immigrants in the Northeast in the early twentieth century. Halbrook, supra note 31, at 819-20; Brent J. McIntosh, The Revolutionary Second Amendment, 51 ALA. L. REV. 673, 704 (2000); Clark Neily, Institute for Justice, Panelist Remarks on Civil Rights: The Heller Case at the Federalist Society Convention (Nov. 20, 2008), in 4 N.Y.U. J.L. \& LIBERTY 293, 314 (2009); see Cottrol \& Diamond, Never Intended, supra note 18, at 1333-34 (linking immigrant-related fears to the passage of New York's Sullivan Law in 1911, and drawing parallels with the South's Post-Reconstruction period). The non-incorporation of the right to keep and bear arms through the Fourteenth Amendment would fly in the face of history and settled jurisprudence. See Kates, Jr., supra note 38, at 253-57 (1983) (providing analysis in favor of Second Amendment incorporation); Neily, supra note 43, at 159 ("[T]he Fourteenth Amendment's ratification history shows quite clearly that [incorporation] is precisely what it was intended to do."). For a thoughtful discussion on the jurisprudence defining the incorporation doctrine and how it applies to the Second Amendment, and concluding incorporation is proper, see Nordyke v. King, 563 F.3d 439, 447-57 (9th Cir. 2009), vacated en banc and remanded for reconsideration in light of McDonald, 611 F.3d 1015 (9th Cir. 2010). For similar discussions coming to opposite conclusions, see Judge Easterbrook's opinion in Nat'l Rifle Ass'n v. City of Chicago, 567 F.3d 856, 857-60 (7th Cir. 2009). See also McDonald, 130 S. Ct. at 3050 (Scalia, J., concurring) ("I have acquiesced in the Court's incorporation of certain guarantees in the Bill of Rights . . ..”); id. at 3059 (Thomas, J., concurring) ("I cannot agree that it is enforceable against the States though a clause that speaks only to 'process.' Instead, the right to keep and bear arms is a privilege of American citizenship that applies to the States through the Fourteenth Amendment's Privileges or Immunities Clause.").

${ }^{49}$ See Heller, 554 U.S. at 594 (recognizing the Second Amendment's conferral of an individual right to bear arms); id. at 636-37 (Stevens, J., dissenting) (recognizing an individual right to bear arms, but only in the context of pursuing militia-related interests); id. at 681 (Breyer, J., dissenting) (agreeing with Stevens's precept, and expounding on the argument that the District's specific firearm regulations comported with the Second Amendment). 
be totally decoupled.

We suggest that American jurists and commentators from the beginning through the McReynolds opinion in United States v. Miller ${ }^{50}$ recognized that the proper linkage between the two parts of the Second Amendment was to view the armed citizenry as an inchoate militia. By virtue of being armed and being experienced with arms, the inchoate militia could be a resource called upon in times of emergency. Proficiency in the use of arms gained from lawful private pursuits could be put to the defense of the community, and indeed the nation. This point was recognized by important legal commentators, including St. George Tucker in his annotations to the first American edition of Blackstone's Commentaries, Justice Story, and Michigan jurist Thomas Cooley, among others. $^{51}$ It was also repeated in much of the nineteenth-century state jurisprudence on the right to bear arms. ${ }^{52}$ The idea of the people at large

50307 U.S. 174 (1939).

${ }^{51}$ Blackstone discussed the Englishman's right to keep and bear arms within a chapter devoted to the "absolute rights of individuals"; Tucker read this as the same right constitutionalized in the new nation by the Second Amendment. 2 William Blackstone, Commentaries 121, 143 \& n.40 (St. George Tucker ed., Philadelphia, William Young Birch \& Abraham Small 1803). Joseph Story wrote:

The importance of [the Second Amendment] will scarcely be doubted by any persons who have duly reflected upon the subject. The militia is the natural defence of a free country against sudden foreign invasions, domestic insurrections, and domestic usurpations of power by rulers. It is against sound policy for a free people to keep up large military establishments and standing armies in time of peace, both from the enormous expenses with which they are attended and the facile means which they afford to ambitious and unprincipled rulers to subvert the government or trample upon the rights of the people. The right of the citizens to keep and bear arms has justly been considered as the palladium of the liberties of a republic, since it offers a strong moral check against the usurpation and arbitrary power of rulers, and will generally, even if these are successful in the first instance, enable the people to resist and triumph over them.

2 Joseph Story, Commentaries on the Constitution of the United States § 1897, at 620 (Thomas M. Cooley ed., 4th ed. Boston, Little, Brown \& Co. 1873). Thomas Cooley wrote:

The Right is General. - It may be supposed from the phraseology of this provision that the right to keep and bear arms was only guaranteed to the militia; but this would be an interpretation not warranted by the intent. The militia, as has been explained elsewhere, consists of those persons who, under the law, are liable to the performance of military duty, and are officered and enrolled for service when called upon. . . . [I]f the right were limited to those enrolled, the purpose of the guarantee might be defeated altogether by the action or the neglect to act of the government it was meant to hold in check. The meaning of the provision undoubtedly is, that the people, from whom the militia must be taken, shall have the right to keep and bear arms, and they need no permission or regulation of law for that purpose.

Thomas M. Cooley, The General Principles of Constitutional LAW In the United StATES OF AMERICA 282 (Alexis C. Angell ed., 2nd ed. Boston, Little, Brown \& Co. 1891).

${ }^{52}$ See Cottrol \& Diamond, Never Intended, supra note 18, at 1319 \& n.71, 1321-23 (discussing militia culture in the nineteenth-century South, and surveying the region's case law then attempting to balance the right to bear arms with public safety concerns). 
acting as an inchoate militia that could assist in the defense of the community and the nation was also recognized by the Supreme Court in the 1886 case Presser v. Illinois, ${ }^{53}$ and as late as 1939 in Miller. ${ }^{54}$

This idea of the population at large as an inchoate militia should be seen within the context of a republican political theory that saw both citizen virtue and citizen participation as essential to preserving the liberties of the community. The militia of the whole envisioned in the Second Amendment was to be valued not merely for its contribution to the defense of the state but also, as the amendment's very language sets out, for helping to maintain a free state. Participation by all would prevent the development of a separate arms-bearing caste: a caste that would view its interests as distinct from those of the citizenry at large — a caste that might one day be used against the very people they were enlisted to protect. So widespread was this view concerning the political value of the militia at large that even that advocate of strong central power, Alexander Hamilton - who thought very little of the military value of the militia of the whole-felt compelled to advocate arming the people at large and requiring them to show up once or twice a year and demonstrate a minimum proficiency with their weapons. ${ }^{55}$

53116 U.S. 252, 265 (1886) ("It is undoubtedly true that all citizens capable of bearing arms constitute the reserved military force or reserve militia of the United States as well as of the States, and, in view of this prerogative of the general government, as well as of its general powers, the States cannot, even laying the constitutional provision in question out of view, prohibit the people from keeping and bearing arms, so as to deprive the United States of their rightful resource for maintaining the public security, and disable the people from performing their duty to the general government.").

${ }^{54}$ Miller, 307 U.S. at 179 ("The signification attributed to the term Militia appears from the debates in the Convention, the history and legislation of Colonies and States, and the writings of approved commentators. These show plainly enough that the Militia comprised all males physically capable of acting in concert for the common defense. 'A body of citizens enrolled for military discipline.' And further, that ordinarily when called for service these men were expected to appear bearing arms supplied by themselves and of the kind in common use at the time.”).

${ }^{55}$ In The Federalist No. 28, Hamilton is unequivocal in his support for an armed citizenry. Moreover, his statements seem to support the individual rights view. He advocated the militia as the primary force to put down emergencies caused by "slight commotion." THE FEDERALIST No. 28 (Alexander Hamilton) (ABA ed., 2009). This reliance on the militia and their readiness was viewed as a "national presumption." Id. Hamilton's advocacy of arms is more than a mere national security strategy, but a staple of his political philosophy as well: "If the representatives of the people betray their constituents, there is then no resource left but in the exertion of that original right of self-defense which is paramount to all positive forms of government ....” Id. at 151. Further, Hamilton's view of federalism and the people's role within the American federal system support a view that the right of the people is incorporated against the states:

[T]he general government will at all times stand ready to check the usurpations of the state governments, and these will have the same disposition toward the general government. The people, by throwing themselves into either scale, will infallibly make it preponderate. If their rights are invaded by either, they can make use of the other as the instrument of redress. 


\section{The SECOnd AmEndment as Moral Statement}

But if the militia and the armed citizenry were seen as serving an important political function, they were also viewed, and more importantly for our purposes, as serving an important moral function. The Second Amendment is, in part, a moral statement. The people are courageous and self-reliant. Having, as Madison put it in Federalist 46, "the advantage of being armed," they are not like the dependent peoples of Europe who are forced to rely on the state for protection. ${ }^{56}$ Instead, they are capable of defending themselves and the state, and, if necessary, their liberties against potential governmental usurpation. ${ }^{57}$

This republican preference for the courageous, self-reliant citizen capable of playing a role in his own defense and the defense of his

Id.; see also THE FEDERALIST No. 29 (Alexander Hamilton) (ABA ed., 2009) (“Little more can be reasonably aimed at, with respect to the people at large, than to have them properly armed and equipped; and in order to see that this is not neglected, it will be necessary to assemble them once or twice in the course of the year.”).

${ }^{56}$ THE FEDERALIST No. 46 (Alexander Hamilton) (ABA ed., 2009).

${ }^{57}$ Madison presumed that the people were capable of self-governance and self-discipline and were sufficiently trustworthy to be armed in defense of the nation and of the collective liberties.

Let a regular army, fully equal to the resources of the country, be formed; and let it be entirely at the devotion of the federal government; still it would not be going too far to say, that the State governments, with the people on their side, would be able to repel the danger. The highest number to which, according to the best computation, a standing army can be carried in any country, does not exceed one hundredth part of the whole number of souls; or one twenty-fifth part of the number able to bear arms. This proportion would not yield, in the United States, an army of more than twentyfive or thirty thousand men. To these would be opposed a militia amounting to near half a million of citizens with arms in their hands, officered by men chosen from among themselves, fighting for their common liberties, and united and conducted by governments possessing their affections and confidence. It may well be doubted, whether a militia thus circumstanced could ever be conquered by such a proportion of regular troops. Those who are best acquainted with the last successful resistance of this country against the British arms, will be most inclined to deny the possibility of it. Besides the advantage of being armed, which the Americans possess over the people of almost every other nation, the existence of subordinate governments, to which the people are attached, and by which the militia officers are appointed, forms a barrier against the enterprises of ambition, more insurmountable than any which a simple government of any form can admit of. Notwithstanding the military establishments in the several kingdoms of Europe, which are carried as far as the public resources will bear, the governments are afraid to trust the people with arms. And it is not certain, that with this aid alone they would not be able to shake off their yokes. But were the people to possess the additional advantages of local governments chosen by themselves, who could collect the national will and direct the national force, and of officers appointed out of the militia, by these governments, and attached both to them and to the militia, it may be affirmed with the greatest assurance, that the throne of every tyranny in Europe would be speedily overturned in spite of the legions which surround it.

THE FEDERALIST No. 46 (James Madison). 
community stands at sharp variance with many of the presumptions of modern early twenty-first century American culture. The Second Amendment debate is really less a debate about constitutional interpretation or historical meaning and more a cultural clash between those who, however imperfectly they express it, seek to preserve the republican values of the Framers and those who quite consciously reject those values.

This can be readily seen in much of the debate over both the Second Amendment and gun control more generally. The value of an armed citizenry for community defense is seen as anachronistic in light of the professionalization of military and police forces. The armed citizen is seen as feckless at best, or worse yet as a potential vigilante ready to plunge the nation back into its own dark ages of lynch law and mob justice. The sturdy republican citizen envisioned by the Framers has been replaced by one seen as incapable of her own defense and one who would wreck the civil order if she tried. ${ }^{58}$

All of this has led to a situation radically different than that contemplated by the Framers of the Second Amendment. In place of the partnership that was meant to come with universal participation in the community's defense has come that dependent reliance on a separate caste for the citizen's very survival that the Framers feared. ${ }^{59}$ In all too many urban areas, the courageous citizenry capable of both self and community defense has been replaced by a fearful population cringing before what the late essayist Christopher Hitchens once aptly termed in The Nation magazine the "duopoly of force" possessed by the police and professional criminals. ${ }^{60}$

This dependency, of course, helps exacerbate the distance between the police and the community. Police and the communities they serve are frequently not partners, no matter how hard public relations officers attached to police departments try to sell that idea. ${ }^{61}$ Police officers realize

58 See Rick Nagin, The Second Amendment Is a Dangerous Anachronism, PEOPLESWORLD.ORG (Jan. 9, 2013), http://peoplesworld.org/the-second-amendment-is-a-dangerous-anachronism/ (calling the Second Amendment a dangerous anachronism).

${ }^{59}$ The dependence on the police is in direct contradiction to the law. It has been held, and is wellsettled, that the police owe no duty to protect the public, generally. This legal conclusion is forced by the empirical facts, for realistically, police cannot defend everyone. Any affirmative legal duty imposed on them in relation to the citizen opens up an array of tort problems for whichever government sponsor the police are operated under. Creamer, supra note 39, at 932-34. Moreover, the increased dependence on police and the decreased ability of citizens trained in arms use for self-defense leads to a waste of "social costs". Todd Barnet, Gun "Control" Laws Violate the Second Amendment and May Lead to Higher Crime Rates, 63 Mo. L. REV 155, 155 (1998).

${ }^{60}$ Christopher Hitchens, The Myth of Gun Control, NATION, Jan. 24, 1994.

${ }^{61}$ Richard Chackerian, Police Professionalism and Citizen Evaluations: A Preliminary Look, 34 Pub. Admin. REV. 141, 141 (1974) (“[W]hen the police and the public are at odds, the police tend to turn to one another for social support, isolating themselves from the community and its needs. Low public evaluation of the police not only affects police attitudes and values, but it also affects citizen 
they are a group apart. Even under the best of circumstances their priorities and those of the communities they serve diverge. In middle-class communities with relatively low crime rates and populations that are able to articulate their political needs, that divergence can still yield unfortunate results. In inner-city communities when the added difficulties of race, class, and political powerlessness are added to the mixture, the results can often be far worse.

The police who are relied upon for protection in our society often have wildly contrasting images. If the popular culture, the crime pages of our local newspapers, and exhaustive social science studies are to be believed, police departments contain within their ranks both sophisticated state of the art forensic experts and bumbling idiots. Some police officers exhibit superhuman courage and self-sacrifice, others can be indifferent to the pain crime brings to ordinary civilians. There are police officers that regularly risk life and limb protecting strangers, often strangers of different races or strangers whose cultural practices are different and at times quite alien. Others are thugs who have made their state-issued badges and guns licenses to bully. In the popular mind and in reality, police are both admired and feared, respected, and hated.

Police are aware of this mixed image. Some spend much of their time in their interaction with the public trying to, in the words of the popular song "accentuate the positive" and "eliminate the negative." 62 Others go about their jobs trying to ignore public perceptions. For yet others, negative images become one more point of friction between the police and community, another reason to view the world in "us vs. them" terms.

This idea of a separate alienated caste was not envisioned by those who founded modern police forces. The officers of the first modern police force, established in Robert Peel's London in 1829, were instructed that the police officer "will be civil and attentive to all persons of every rank and class; insolence or incivility will not be passed over." ${ }^{\text {"3 } 3}$ Moreover, these officers were told, a police officer must be "particularly cautious, not to interfere idly or unnecessarily." 64 They were also warned: "there is no qualification so indispensable to a police-officer as a perfect command of

cooperation with police in the law enforcement process. A citizenry which is hostile to the police is less willing to report suspicious persons, to testify, or to provide information.”). Police often have negative outlooks concerning social and legal institutions, and their role within each. See David M. Rafky, The Cognitive Gap Between the Police and the Policed: An Exploratory Study in Attitude Organization, 1 LAW \& HuM. BEHAV. 63, 65 (1977) (discussing the content of police and student beliefs).

${ }^{62}$ JohnNy Mercer, ACCentuate the Positive (Capitol Records 1944).

${ }^{63}$ P.A.J. WAdDington, Policing Citizens: Authority AND Rights 23 (1999).

${ }^{64} I d$. 
temper.",65

But the London Bobby's ideal of unarmed civility lost something in the trip across the Atlantic. To indulge broad stereotypes, perhaps the rough and tumble nature of American society, the unwillingness of Americans to defer to their betters, to accept their "station" in life helped create a more violent criminal atmosphere. Certainly ethnic and racial conflict played a role in making the American city more dangerous, ${ }^{66}$ or seemingly more so than Victorian London, Charles Dickens's vivid portraits notwithstanding. By the end of the nineteenth and the beginning of the twentieth centuries, large-scale immigration from Southern and Eastern Europe helped breed fear of new "dangerous classes." 67 Ethnic antagonism combined with self-assured pseudoscience to help license rougher police procedures. Violations of civil rights and individual dignity, at least the dignity of those from the "dangerous classes," became routine: the third degree standard procedure. ${ }^{68}$ Much of this did not begin to lessen until relatively recently when the federal courts began to take a serious role in the regulation of police behavior. ${ }^{69}$ In many poor communities, all too many ordinary citizens came to fear hostile encounters with police as much as they feared the predations of

65 T.A. CRitchley, A History of Police in England And Wales 53 (1967); see Peter Evans, The Police Revolution 46 (1974) (noting the origin of the English police under Sir Robert Peel); Martin Alan Greenberg, Auxiliary Police 22 (1984) (describing English police under Robert Peel); see also Peter K. MAnning, Police Work: The Social Organization of Policing 19 (1977) ("The most visible activity of the police, that for which they were conceived and by which they are best known, is preventive patrol," the core activity of police work as defined by Robert Peel); id. at 74-83 (describing Robert Peel's history and political strategy); id. at 234 (listing excerpts from field notes describing the proper emotional tone and demeanor of a policeman); JEROME H. SKOLNICK \& David H. Bayley, The New Blue Line: Police InNovation in SiX Americans Cities, at viii (1986) (describing the historical police attitude as a "distant, technically orientated professionalism").

${ }^{66}$ See Jerome H. Skolnick \& James J. Fyfe, Above the Law: Police and the Excessive USE OF FORCE 25-29 (1993) (describing how ethnic and racial conflicts encouraged some to take the law into their own hands); see also W. MARVIN DULANEY, BLACK POLICE IN AMERICA, 1-7, 31 (1996) (describing how the first southern police forces were established not on the "British model," but for the specific purpose of intimidating and controlling Blacks, including, for example, the Louisville, Kentucky police force); Cottrol \& Diamond, Never Intended, supra note 18, at 1324-28 (describing post-Civil War legislative limitations on the rights of Blacks). See generally JAMES F. RICHARDSON, URBAN POLICE IN THE UNITED STATES 19-34 (1974) (describing the establishment of organized police in the United States during the eighteenth and nineteenth centuries).

${ }^{67}$ DuLANEY, supra note 66, at 2-3; see also Larry Catá Backer, Welfare Reform at the Limit: The Futility of "Ending Welfare as We Know It," 30 HARV. C.R.-C.L. L. REV. 339, 347-50 (1995) (describing how poverty is used as justification for unequal treatment); Cottrol \& Diamond, Public Safety and the Right to Bear Arms, supra note 17, at 88-107 (describing the evolution of the right to bear arms in the United States).

${ }^{68}$ See Mark H. Haller, Historical Roots of Police Behavior: Chicago 1890-1925, 10 LAW \& SOC'Y REV. 303, 304, 320-21 (1976) (describing police sanctioned violence and violations of individual rights, and that these were seldom recorded in an era before civil liberties organizations).

${ }^{69}$ See id. at 322-23 (noting a variety of factors, including the influence of courts, changed police attitudes during the twentieth century). 
criminals. $^{70}$ This was true of immigrants from Southern and Eastern Europe. ${ }^{71}$ It was also true of southern Negroes fleeing the Jim Crow South for the often cold comfort of northern and western cities. ${ }^{72}$

The brutalities that were common in the early part of the twentieth century have lessened. Judicial determinations ${ }^{73}$ and, no doubt, police professionalization and the general development of more enlightened ethnic and racial attitudes have contributed to this. But the kind of mutual distrust that has characterized police community relations in the past persists, fueled by high levels of violence in inner-city life. ${ }^{74}$ This is understandable. Police officers, particularly patrol officers in dangerous communities, rarely see their fellow citizens at their best. Their professional worlds are disproportionately inhabited by predators and

${ }^{70}$ See, e.g., MARILynN Johnson, StREet Justice: A History of Police Violence In NEW YORK CITY 57-86 (2003) (discussing police violence against blacks and Jews in New York City from 1900-1911, and the responses of those groups to the violence); Frank Moss, Persecution of Negroes by Roughs and Policemen, in the City of New York, August 1900, in Police Brutality: An AnTHOlOGY 60-87 (Jill Nelson ed., 2000) (providing examples of affidavits, from both blacks and whites, describing incidents of police brutality and indifference against black residents of New York City in 1900). This distrust has manifested itself into the "stop snitching" movement, where many citizens in poor urban communities do not talk to police or help them solve crimes, partly out of distrust and partly out of the fear of criminal reprisal. See COMMUNITY ORIENTED POLICING SERVICES, U.S. DeP'T OF Justice, The Stop Snitching Phenomenon: BREAKIng the Code of Silence 10 (2009), available at http://cops.usdoj.gov/Publications/e030919195-Stop-Snitiching.pdf [hereinafter STOP SNITCHING] (defining the "stop snitching" phenomenon).

${ }^{71}$ Cottrol \& Diamond, Public Safety and the Right to Bear Arms, supra note 17, at 98-99. In 1911, in response to the perceived threat from immigrants from Southern and Eastern Europe, New York passed the Sullivan Law, making it a felony to carry an unlicensed weapon, or to purchase or own a pistol without a permit. This law was aimed primarily at immigrants from southern and eastern Europe who were residing in New York City. Id.

${ }^{72}$ The Second Great Migration, AAME, http://www.inmotionaame.org/print.cfm;jsessionid=f830 1723641366085448660?migration=9\&bhjs=0 (last visited Apr. 28, 2013).

${ }^{73}$ See, e.g., Tennessee v. Garner, 471 U.S. 1, 3 (1984) (holding unconstitutional certain applications of the fleeing felon rule, which allowed police to use any means necessary to arrest a suspected felon, including killing); see also SKOLNICK \& FYFE, supra note 66, at 48-61, 64-66 (1993) (analyzing various Supreme Court cases impacting the evolution of modern criminal procedure); Kevin P. Jenkins, Police Use of Deadly Force Against Minorities: Ways to Stop the Killing, 9 HARV. BLACKLETTER J. 1, 5-7 (1992) (examining the fleeing felon rule under the common law and in Tennessee v. Garner, 471 U.S. 1 (1984)); Robert V. Ward, Consenting to a Search and Seizure in Poor and Minority Neighborhoods: No Place for a "Reasonable Person," 36 How. L.J. 239, 242-45, 24953 (1993) (discussing Terry v. Ohio, 392 U.S. 1 (1968), Schneckloth v. Bustamonte, 412 U.S. 218 (1973), United States v. Mendenhall, 446 U.S. 544 (1980), I.N.S. v. Delgado, 466 U.S. 210 (1984), and Florida v. Bostick, 501 U.S. 429 (1991), and their implications to the minority community).

${ }^{74}$ E.g., ANDREW Hacker, Two Nations: Black AND White, SeParate, Hostile, Unequal 47 (1992). Specifically concerning continued mistrust, top levels of the Philadelphia police force used a website as a platform for their racist views. Racist Rants Condoned by Cops, Suit Says, CNN.COM BLOG (July 21, 2009 9:36 AM), http://am.blogs.cnn.com/2009/07/21/philadelphia-police-called-bigotswith-badges. A lawsuit is reportedly pending. Guardian Civic League v. Phil. Police Dep’t, DigitaL MediA L. Project (Aug. 5, 2009), http://www.dmlp.org/threats/guardian-civic-league-v-philadelphiapolice-department; see also Ward, supra note 73, at 242-45, 249-53 (discussing consent decrees in a series of U.S. Supreme Court cases). 
prey. ${ }^{75}$ Many see, on a far too frequent basis, monstrous crimes, crimes that often have little in the way of either justification or increasingly even rational motive. ${ }^{76}$ It can create strong cynicism as even many sympathetic observers of police life have noted.

And they are afraid, justifiably so. Police are targets. And if the empirical evidence reveals that, on the whole, police work is actually less dangerous than some other occupations - cab drivers or convenience store clerks in inner-city neighborhoods come readily to mind-that is scarce comfort to a patrolwoman approaching a stopped car at night, or a patrolman going into an apartment house after shots have been fired.

But the horrors and dangers of the job are not alone in creating a sense of alienation and mistrust. ${ }^{77}$ Police frequently see themselves as the unappreciated "thin blue line," between civilization and barbarism. ${ }^{78}$ From their point of view, the criminal justice system and the public they risk their lives to protect not only fail to appreciate their efforts, but also often act to frustrate those efforts. Their efforts, they believe, are frustrated by a criminal justice system overly concerned with technical niceties rather than what they argue is the clear guilt of those they arrest. $^{79}$

${ }^{75}$ See MANNING, supra note 65, at 236 (providing typifications posed by officers of events, persons, and places encountered).

${ }^{76}$ Thomas Moore et al., Dead Zones, U.S. NEWS \& WoRLD ReP., Apr. 10, 1989, at 20.

${ }^{77}$ See KNAPP COMMISSION REPORT ON POLICE CORRUPTION 6 (1972) ("Nobody . . . likes to have his activities interfered with. As a result, most citizens, at one time or another, regard the police with varying degrees of hostility. The policeman feels, and naturally often returns, this hostility.”). Both the dangers of the job and the hostility police officers receive from society contribute to the intense group loyalty within the profession. This loyalty, in turn, fosters pride in their jobs, as well as suspicion of, and hostility towards, outsiders.

${ }^{78}$ See Herbert T. Klein, The Police: Damned IF They Do, Damned if They Don'T 211-12 (1968) (describing the "thin blue line" as the embodiment of the separation of order and anarchy); Charles J. Ogletree, JR. et AL., Beyond the Rodney King Story: An InVestigation OF Police Misconduct IN MinORITY Communities 17-18 (1995) [hereinafter BEyond tHE RodNEY King STORY] (detailing a variety of widely-held beliefs about police culture, including the idea that "[n]o one outside police departments . . . can understand what police officers have to do"); JAMES F. RichaRdSON, URBAN POLICE IN THE UNITED STATES 139-44 (1974) (describing the purpose and view of the police force as seen by William Parker, who served as the Chief of Police of the Los Angeles Police Department from 1950-1966).

${ }^{79}$ See Edward E. Shev \& Jeremy Joan Hewes, Good Cops, Bad Cops: Memoirs of a Police PSYCHIATRIST 96-101 (1977) (detailing officer feelings and comments during informal group meetings). During a "bull session" with Sausalito Police Department station officers, the conversation turned to officers' complaints about the public's feelings towards police officers. Id. at 96. Comments included, "the general public doesn't give a damn about the police," police officers are the only ones handling violent situations other agencies avoid, and even though the police know that the people they arrest are routinely back out on the streets shortly after being arrested, police officers do not give up even though the court and the government systems are "so fouled up they can't do their jobs." Id. at 101. "Society's garbagemen" was the descriptive phrase offered by the psychiatrist leading the discussion. Id. Another officer noted that police officers are "the only ones keeping the wolf away from the door." Id. The purpose behind these sessions was to let the officers voice their opinions, as well as to make officers feel that their observations and opinions were shared by their counterparts. Id. With a healthier perspective on their work, the participants were less likely to go on the street paranoid, 
From their point of view, the public that screams for more protection is often unwilling to provide cooperation by acting as witnesses or swearing out complaints. $^{80}$ Of course, many members of the public see the problem in exactly opposite terms. Why, many ask, should I risk retaliation by identifying criminals when it is obvious the police cannot or will not protect me? ${ }^{81}$ The cycle continues.

\section{RACIAL ANTAGONISM AND INEFFECTIVE POLICING}

All of this is exacerbated by race and class. The police officer coming into a ghetto community from the outside will likely feel an even greater sense of estrangement from the community, repelled by a level of violence that she had probably not encountered in her upbringing. ${ }^{82}$ Negative stereotypes about African Americans, or at least poor black people, are likely to be reinforced. ${ }^{83}$ Even police officers with inner-city backgrounds are likely to be pulled in conflicting directions. Their understanding and empathy for ordinary citizens in inner-city communities - the most victimized people in our society ${ }^{84}$ — is likely to be tempered by the desire

and also were less likely to react to the public as a "collection of criminals or disgruntled taxpayers who want to make the cop's life miserable.” Id. at 102; see also ANTHONY V. BOUZA, THE POLICE MYSTIQUE: AN INSIDER's LOOK AT COPS, CRIME, AND THE CRIMINAL JUSTICE SYSTEM 159-60 (1990) (arguing that as a result of police officers acting in their capacities to promote public safety regardless of cost or "legal niceties," the Constitution has often refined their powers and stymied their efforts). Stemming from courts balancing the "power and efficiency of the state versus the freedom of the individual" when deciding cases involving police powers and functions, police officers often find that decisions restricting their abilities to perform their professional duties amount to "handcuffing the police.” Id. (internal quotation marks omitted).

${ }^{80}$ See Stephen Leinen, Black Police, White Society 152-53 (1984) (noting various firsthand experiences of police officers and their interactions with the general public); see also BEYOND THE RODNEY KING STORY, supra note 78, at 52-70 (finding that police misconduct is even more unlikely to be complained about by the public, as impediments such as retaliation can occur, procedures for doing so are generally unpublicized, police routinely pressure citizens against filing such complaints, and results are often dissatisfactory); STOP SNITCHING, supra note 70, at 10 (highlighting the disturbing tendency for people to not cooperate with police investigations).

${ }^{81}$ See SKOLNICK \& BAYLEY, supra note 65, at 189 (1986) (noting that at one time Newark, New Jersey, in response to an overwhelming amount of 911 calls, employed an answering machine with operators that hung up if they thought the call was "insignificant”; and that over time, citizens had to learn to manipulate the system in order to get police to respond to their calls); see also Paul $\mathrm{J}$. Arougheti, Imposing Homicide Liability on Gun Battle Participants for the Death of Innocent Bystanders, 27 CoLUM. J.L. \& SoC. PROBS. 467, 474 (1994) (maintaining that retribution is a major factor contributing to the reluctance of crime witnesses to come forward, or to identify themselves in the event that they do).

${ }^{82}$ Leinen, supra note 80, at 127-29; JAMEs F. Richardson, Urban Police in the United STATES 173; SKOLNICK \& BAYLEY, supra note 65, at 19.

${ }^{83}$ LeInEN, supra note 80, at 127-29; Robin K. Magee, The Myth of the Good Cop and the Inadequacy of Fourth Amendment Remedies for Black Men: Contrasting Presumptions of Innocence and Guilt, 23 CAP. U. L. REV. 151, 207-08 (1994).

${ }^{84}$ See BouzA, supra note 79, at 141 (noting that "blacks can be relied upon to deal more sympathetically and sensibly with other blacks”). 
to fit into the police culture, a culture that has been shaped by a regular pattern of negative encounters with ghetto residents. ${ }^{85}$ The tendency to overreact with brutality or to develop an indifference to the plight of victims will be great. ${ }^{86}$ This in turn fuels suspicion of the police causing inner city residents to regard cooperation with the police as futile and perhaps foolhardy. Racial antagonism, of course, only increases the problem.

Black people are disproportionately likely to be among the perpetrators of the kind of street crime that makes our inner cities increasingly dangerous. These crimes are overwhelmingly committed against black victims. In 2008, the homicide victimization rate for the black population was six-times higher than the rate for white population. ${ }^{87}$ The homicide offender rate for blacks was seven-times the rate for whites. ${ }^{88}$ Although African Americans constitute $12 \%$ to $14 \%$ of the American population, ${ }^{89}$ in 2011 over $28 \%$ of those arrested for felonies and over $45 \%$ of those arrested for intentional homicides were black. ${ }^{90}$

There is, of course, no shortage of sociological explanations for the high crime rate in inner-city Black communities. Racism in the nation's past, and unfortunately lingering racism in its present, has contributed to

${ }^{85}$ See Beyond the Rodney King Story, supra note 78, at 72-73, 102 (stating that black officers often keep silent about police misdoings to protect their careers and advancement opportunities). Police officers from minority or inner-city backgrounds face racism from within the department and are faced with two choices: (1) go along with the other cops; or (2) risk further alienation by expressing empathy for residents. See id. at 19, 80 (citing an example of one police officer who faced alienation after refusing to use greater force than he felt was necessary); REPORT OF THE IndePendent Commission on the Los ANgeles Police Department 79-80, 82, 170 (Christopher Commission 1991) (discussing problems related to the bias treatment of minority police officers and racial injustices within the departments). There is also another conflict endured by minority officers: either to endure the rampant racial slurs and blatant harassment or complain and risk alienation and ostracism, which can prove to be dangerous in police work. See LEINEN, supra note 80, at $127-30$.

${ }^{86}$ DulANEY, supra note 66, at 104-06. African-Americans were often recruited and placed in Black neighborhoods for the specific purpose of using force against Blacks. Many officers gained notoriety and acceptance among whites for their deeds. See supra note 36 (discussing Black officers assigned to "black beats"). More recently, Black officers have been placed in Black communities supposedly to curb crime among persons to whom they can relate. However, this often backfires, as inner-city residents (and the officer himself) see the officer as neither black, nor white, but blue, and the officer sees the citizens, not as fellow African Americans, but as automatically guilty-until-provenotherwise criminals. See LEINEN, supra note 80, at 175 (discussing the tensions between the community's feelings towards the police and the police's feelings towards the community).

${ }^{87}$ HOMICIDE TRENDS IN THE UNITED STATES, supra note 16, at 11.

${ }^{88} \mathrm{Id}$.

${ }^{89}$ Black or African American Populations, Ctrs. FOR Disease Control \& Prevention, http://www.cdc.gov/minorityhealth/populations/REMP/black.html (last visited Mar. 27, 2013).

${ }^{90}$ Crime in the United States (2011), U.S. DeP’T Justice, CRIMINAL Justice InFO. Servs. Div., available at http://www.fbi.gov/about-us/cjis/ucr/crime-in-the-u.s/2011/crime-in-the-u.s.2011/tables/table-43. 
this tragedy. Structural economic changes have also played a part, ${ }^{91}$ as has the attractiveness of illegal means of acquiring money. And perhaps most important, the disturbing growth, particularly among many young people, of a culture of despair-a self-destructive underclass culture alien not only to middle-class American culture but the cultural values traditionally held by poor black people as well-has helped create a crisis in crime in the inner city and one that police departments have not been able to alleviate.

If experience and racial antagonism have caused many police officers to view inner-city communities as tangled webs of pathological behavior complete with vicious criminals and unhelpful victims, many inner-city residents have come to see police forces as uncaring occupiers largely unconcerned, unwilling, or unable to take meaningful steps to make their daily lives safer. There are many reasons for this. One reason is corruption. If police, like other public servants, feel underpaid and underappreciated, they are often in a better position to do something about it. The problem of freelance, opportunistic, police corruption has long been known. It occurs at relatively benign levels-police who get free meals at restaurants or who take money to forget about minor traffic violations. Corruption can also take more sinister forms, such as shaking down prostitutes for sex or removing property from crime scenes. Police corruption has also been more systematic during times when prohibitions on widely demanded goods have brought high profits to organized crime. This has been a longstanding concern, one that had significant impact on the nation's police departments during the national experiment with alcohol prohibition in the twenties. ${ }^{92}$ In more recent decades, the War on Drugs has increased fears on the part of many that drug prohibition has helped escalate corruption in numerous police departments. ${ }^{93}$ And although police are widely believed to enforce their own code of silence, many instances of systematic corruption have been uncovered due to the efforts of conscientious police officers. For example, former New York Police Detective Frank Serpico’s revelations concerning police corruption

${ }^{91}$ See John Ingram, Globalization, Inner City Crime and the Coming Legitimacy Crisis, 2 JusT. POL'Y J. 4, 8 (2005) (discussing a recent shift in economic and social policy in developed nations and the creation of high crime rates in economically depressed areas).

${ }^{92}$ See Julien Comte, "Let the Federal Men Raid": Bootlegging and Prohibition Enforcement in Pittsburgh, 77 PA. HIST. 166, 167, 170, 176 (2010) (discussing the “endemic corruption” during prohibition in the 1920s and early 1930s); Kenneth D. Rose, The Labbe Affair and Prohibition Enforcement in Portland, 77 PAC. NW. Q. 42, 50 (1986).

93 See Eric Blumenson \& Eva Nilsen, Policing for Profit: The Drug War's Hidden Economic Agenda, 65 U. CHI. L. REV. 35, 41, 79, 95-96, 99 (1998) (discussing the "destructive impact" of the War on Drugs, particularly concerning the corruption of law enforcement when placed in intimate undercover operations with criminals and drugs); Bruce D. Johnson et al., Drug Abuse in the Inner City: Impact on Hard-Drug Users and the Community, 13 CRIME \& JUST. 9, 31 (1990) (discussing a surge in freelance drug sellers in New York City following tactics employed by the NYC Police Department to prevent future police corruption). 
in New York City brought to light the problem of widespread corruption and the informal, but intense, pressures that kept many police officers from revealing wrongdoing on the part of fellow officers. ${ }^{94}$

If corruption and indifference convince many inner-city residents that police will provide little help in their struggle against violent predators, confrontations between police and residents of inner-city communities serve to increase the distance between residents of high-crime communities and the very people who are supposedly their protectors. At times, these contacts occur with vivid examples of police brutality. More often they involve routine arrests and questioning of young black men, the group most likely to be both the victims and perpetrators of ordinary street crime. In many venues, New York City is but one example, it is official policy to allow the police wide latitude to question young men in black and Latino communities. Fourth Amendment search and seizure protections in these contexts have become a constitutional fiction. ${ }^{95}$ All of this increases fear of the police on the part of many inner-city residents. This fear, in turn, contributes to a reluctance to call on the police for assistance or to cooperate with police officials. And police brutality, including often highly questionable shootings of black men by police that occur in many of the nation's cities, also helps create sympathy for criminals on the part of an uncomfortably large number of law-abiding inner-city residents. The belief persists, often justified by personal experience, that in encounters between police and those accused of criminal misconduct, it is often hard to distinguish the heroes from the villains.

The problems that contribute to the mutual estrangement and alienation between the police and the communities they serve exist to varying degrees in all communities, but the problem is most acute in the poor, black inner cities. We have, unwittingly to be sure, created a society helpless in the face of criminal violence and yet afraid of the police. Citizens of the inner city see the meager share that they have been granted of the nation's abundance reduced even further by criminal predators, yet are concerned that if the police act at all, that they will often act with unjustified violence against innocent members of the community. We also have a citizenry that realizes that even if police attitudes and behavior should improve dramatically, the police will still be incapable of significantly curtailing the crime that limits all of our freedoms. The problem of crime is too large,

\footnotetext{
${ }^{94}$ See generally PETER MAAS, SERPICO (1973) (discussing how one police officer, Frank Serpico, attempted to fight the culture of corruption among the New York Police Department).

${ }^{95}$ This has been vividly illustrated with the stop and frisk policy that has been implemented in New York City. See Joseph Goldstein, Trial to Start in Class Suit on Stop-and-Frisk Tactic, N.Y. TIMES (Mar. 17, 2013), http://www.nytimes.com/2013/03/18/nyregion/stop-and-frisk-trial-to-open-thisweek-in-federal-court.html (discussing the suit filed by four black men against the city, claiming that the police improperly targeted them because of their race and that the tactic violated their constitutional right against unreasonable searches).
} 
the number of police too few. And in recent years budget constraints have led to cut backs in police personnel, an indicator that in some communities even the inadequate levels of police protection that they had in the past will be further reduced. ${ }^{96}$ Threatened and helpless, the people of the inner cities deserve answers that will loosen the grip of crime on their communities.

\section{TOWARD A WELL-REgUlated Militia}

An increasing number of observers are coming to recognize that in order to fight crime in the inner cities, it is going to be necessary to break the cycles of estrangement, dependency, and withdrawal that all too often characterize relations between citizens in the inner city and urban police departments. The moves toward community policing, neighborhood watches, and similar activities are all evidence of this recognition. We want to suggest that as important as these initiatives are, the scarcely considered alternative of reviving and modernizing the classical republican notion of arming and training the community to play a role in its own defense has still greater potential to restore courage and self-respect, create a new, more positive relationship between the police and the citizens, and equally important, to reduce the rates of certain kinds of violent street crime.

Anyone who advocates this revival of the militia of the whole as a means of fighting crime in the contemporary inner city will be subject to a barrage of criticism. Some of this will be simplistic and easy to dismiss (i.e., "Should they drill with muskets in the town square, waiting for redcoats?”). Other critics will charge that such a revival would be either an invitation to vigilantism or that it could devolve into such with relative ease. Still others will bring up very real problems concerning standards of training, the danger of arming and deploying partially trained people on our city streets, tort liability, workers' compensation, and similar issues. While space will not permit us to treat all of these issues, we would like to outline what we think such a project might look like and deal with some of the principle benefits and objections.

First, we should recognize that any plan to increase citizen participation in community and self-defense could build on existing

${ }^{96}$ See David Schaper, Milwaukee County Sheriff: 'You Have a Duty to Protect Yourself', NPR (Jan. 31, 2013), http://www.npr.org/2013/01/31/170727538/milwaukee-sheriff-advises-residents-toarm-themselves (describing a warning that the Milwaukee County Sheriff gave to residents, telling them that they should be prepared to defend themselves in emergencies instead of just relying upon authorities, especially after recent budget cuts); Steve Tawa, Camden City Council Rubberstamps Layoff of City's Entire Police Department, CBS LOCAL (PHILA.) (Jan. 24, 2013), http://philadelphia.cbslocal.com/2013/01/04/camden-city-council-rubberstamps-layoff-of-citys-entirepolice-department (reporting that the Camden City Council voted to lay off all of the city's uniformed officers and planned to create a "metro" police department administered by the county). 
models of such participation. In a number of jurisdictions there are reasonably successful working examples of auxiliary police programs whose members go through a modified version of police training, are armed, and patrol, usually in partnership with regular officers. ${ }^{97}$ Similarly, armed private security guards, usually with considerably less training, guard private property and are increasingly being used to guard private residence complexes and at times whole communities. Finally, large numbers of people own firearms for self-protection-by most estimates there are firearms in roughly one-half of the homes in the country. ${ }^{98}$

All of this can provide a foundation for greater citizen involvement in protecting communities in our desperate inner cities. In a more systematic fashion than is being tried in any community that we are aware of, we need to unify the four existing examples of citizen participation-auxiliary police, security guards, and private self-defense-into a well-integrated system of police training, citizen participation, and mutual reliance. Over time there should be an effort to gradually and significantly increase the number of citizens participating in such an effort so that the concept, still recognized by law, that the citizenry constitutes a reserve force who have a role in maintaining the security of the community goes from being a matter of theoretical interest to a living reality in the lives of most Americans, particularly those most in need of this kind of empowerment.

\section{A. Armed and Trained Auxiliaries}

Probably the most important and most difficult part of such an effort would be to convince significant numbers of citizens to take the effort to become full-fledged auxiliary police officers. These officers, like their regular counterparts, would have full-fledged peace officer status, arrest powers, and authority to carry firearms without licenses. Recruiting people to such a program would be difficult, particularly in many inner-city communities. Participation would entail some degree of sacrifice on the individual's part. Based on the experience of the Los Angeles Police Department's Police Reserve program, it would take a minimum of four months of intensive part-time training for reserve or auxiliary officers to gain the minimum proficiency required to serve as part-time sworn officers. $^{99}$ Training time could be reduced for military veterans. Entry standards would be roughly equivalent to those for regular police officers,

\footnotetext{
${ }^{97}$ See infra note 99 (discussing Los Angeles Police Reserve program).

${ }^{98}$ Lydia Saad, Self-Reported Gun Ownership in U.S. Is Highest Since 1993, GALLUP POL. (Oct. 26, 2011), http://www.gallup.com/poll/150353/self-reported-gun-ownership-highest-1993.aspx.

${ }^{99}$ See Reserve Police Officer Program, L.A. POLICE DEP'T, http://www.lapdonline.org/join_the_team/content_basic_view/542 (last visited Mar. 27, 2013) (describing the different levels of the program, standard requirements for applicants, and the rewards of becoming a reserve officer).
} 
though some modification of educational and physical standards might be desirable, particularly as a way of recruiting older, more experienced persons from inner-city communities to join an auxiliary or reserve program. ${ }^{100}$

Despite these kinds of difficulties, getting widespread participation in the auxiliary program would be especially important in terms of breaking down this highly destructive sense of the police as a separate caste. Auxiliaries or reservists would train most intensively with regular police. They would patrol with them. They would be from the community and able to help regular police, many of whom would be outsiders, understand the community. And these auxiliaries would be full-fledged police officers. The knowledge that there were large numbers of such people less beholden to an insider's tunnel vision, physically and legally empowered to stop acts of police misconduct, and whose testimony would be highly credible at any hearing concerning allegations of misdeeds on the part of police officers would serve as a strong deterrent. The presence of ordinary citizens from the community serving in this auxiliary capacity could also help bring the community's sense of priorities to the business of going after crime and protecting neighborhoods.

We are aware that there will be tensions between auxiliaries and regulars. In fact, auxiliaries are likely to be the object of considerable resentment initially. Concerns will range from those of unions that fear that such a force will dilute the demand for more regular police officers, to a resentment of outsiders who will intrude into the "brotherhood in blue," to the very reasonable fear on the part of regulars that their auxiliary partners might be less reliable in emergency situations. Some of this resentment will likely diminish over time as regulars train, work with, and come to depend on auxiliaries. In many ways a parallel might be drawn with the experience of regular army soldiers during wartime. They initially resent the civilians in uniform, the reservists, the draftees and the wartime volunteers that they are forced to train and lead during the emergency. But they come to realize that they are essential to getting the job done and that they often bring unexpected strengths to the enterprise.

\section{B. An Armed and Visible Neighborhood Watch}

While the auxiliary police program would involve the most dedicated and intensely trained citizen participants, the second tier of involved citizens would be trained as security guards. These individuals would

100 The Los Angeles Police Department divides its reserve officers into three level categories, Levels I, II, and III. Level III reservists are the lowest level category. They are qualified for armed duty, but are generally restricted to administrative and public relations duties. They have to undergo 240 hours of training with a training regimen that requires on average eighteen hours per week. Levels I and II reservists assist in patrol work and require additional training. 
receive, from the police department, a level of training roughly equivalent to armed private security guards. Training requirements for armed security guards vary in different states, but approximately forty hours of training seems to be common in a number of jurisdictions. ${ }^{101}$ These security guards would function as a kind of armed, highly visible neighborhood watch. Their purpose would be to deter crime, although they would have limited powers to arrest or detain in emergency situations. One could imagine them performing limited security tasks-escorting convenience store clerks or Bodega owners to ATM machines to make night deposits, providing security at bus stops at night, or standing watch in front of churches during services might be examples. People in this program would work at the direction of the police department. In essence this would bring to inner-city communities the benefits of security forces that are already being used to guard businesses and indeed many affluent and middle-class communities. Unlike the auxiliaries, people in the security program would not have peace officer status and would have no more right to carry firearms off duty than other citizens. In jurisdictions that restrict the issuance of licenses to carry firearms, people participating in this program would get preferences for licenses. For both the auxiliary and security programs, states would have to pass legislation protecting the employment rights of people participating in these programs while they are in training or on duty. This legislation could be modeled on existing federal law, which protects the job rights of individuals who are members of the reserve components of the armed forces. ${ }^{102}$

\section{A New Partnership}

The final part of this scheme would involve creating a new relationship between police and ordinary citizens who are firearms owners. In all too many urban communities, the official police posture with respect to firearms ownership and citizen self-defense has ranged from indifference to outright hostility. We believe that even in communities where police departments have relatively good records of protecting the population, responding to emergency calls and deterring crime, the conventional wisdom that citizens should be submissive in the face of physical aggression and totally dependent on the police for their physical security is

101 See, e.g., Armed Security Officer, VA. DEP'T OF CRIMINAL JusticE SERVS., http://www.dcjs.virginia.gov/pss/howto/registrations/armedSecurityOfficer.cfm (last visited Mar. 27, 2013) (providing that in Virginia, armed security officer applicants must undergo 40-42 hours of training, including 18 hours of Core Subjects Entry Level training, 8 hours of training in Armed Security Officer Arrest Authority, 14 hours of Entry Level Firearms Training, and 2 hours of Entry Level Shotgun Training).

102 See generally 20 C.F.R. § 1002 (2012) (establishing job benefits and protections available to members of the reserved forces). 
highly problematic. In inner-city communities, where police forces and the criminal justice system have often egregiously failed to protect the citizens, such advice is unconscionable.

The official posture of indifference or hostility should be replaced with an active training program for inner-city residents. Such a program would involve not only teaching the fundamentals of marksmanship and safe firearms handling, but it would also involve teaching people the law of deadly force and proper rules of conduct in order to minimize the danger that police would confuse the aggressor and the defender when they arrive at the scene of an armed confrontation. Such a program would also involve teaching people how to safeguard their dwellings so that armed force would be a last resort. Again, active police training and working with citizens would be a key to this program.

\section{CONCLUSION}

The scheme we have outlined is not written in stone; there are doubtless many improvements that might be made. But it is a step away from a mode of thinking that we believe has had tragic consequences. We have allowed a relative handful of people to make many of our inner cities virtually unlivable because we have forgotten an ancient insight: the security of a community depends on all the members of that community and not a select few. This unwillingness to be active participants in our own defense has emboldened criminals. Perhaps worse yet, it has created a separation between protectors and protected that is inimical to mutual respect and cooperation between police and citizens. The development of a separate police caste has created the greatest distrust where police and effective law enforcement are most needed: on the dangerous mean streets of our ghettos. If the spread of the criminal subculture that has destroyed all too many inner-city communities is to stop, this must be reversed. Professor Johnson's Firearms Policy and the Black Community has reminded us of the important role that courage, the right to have arms, and the willingness to defend oneself and one's community played in vanquishing the forces of violent racism in the not too distant past. These are important lessons that still have much to teach us. Perhaps by learning from this past we may realize that for those concerned with the scourge of crime in modern urban America, the proper response to the Second Amendment is not to truncate the right to bear arms, but to restore the well-regulated militia. 